UDC 81'42

doi $10.17072 / 2073-6681-2020-3-31-40$

\title{
REIMAGINE PITCH AS A SPEECH GENRE IN BUSINESS COMMUNICATION
}

\author{
Tatiana L. Kopus \\ Associate Professor in the Department of Language Training \\ Financial University under the Government of the Russian Federation \\ 49, Leningradskyi prospekt, Moscow, 125993, Russian Federation. tlkopus@fa.ru \\ SPIN-code: $7478-2763$ \\ ORCID: http://orcid.org/0000-0002-7762-0043 \\ ResearcherID: J-4704-2015
}

\section{Irina I. Klimova}

Professor in the Department of Language Training

Financial University under the Government of the Russian Federation

49, Leningradskyi prospekt, Moscow, 125993, Russian Federation. iiklimova@fa.ru

SPIN-code: $9951-3145$

ORCID: http://orcid.org/0000-0001-5142-1890

Submitted 12.05.2020

\section{Просьба ссылаться на эту статью в русскоязычных источниках следующим образом:}

Kopus T. L., Klimova I. I. Reimagine Pitch as a Speech Genre in Business Communication // Вестник Пермского университета. Российская и зарубежная филология. 2020. Т. 12, вып. 3. С. 31-40. doi 10.17072/2073-66812020-3-31-40

Please cite this article in English as:

Kopus T. L., Klimova I. I. Reimagine Pitch as a Speech Genre in Business Communication. Vestnik Permskogo universiteta. Rossiyskaya i zarubezhnaya filologiya [Perm University Herald. Russian and Foreign Philology], 2020, vol. 12, issue 3, pp. 31-40. doi 10.17072/2073-6681-2020-3-31-40 (In Russ.)

The article studies system-forming characteristics of pitch as a business speech genre in business communication. The research material is presented by 54 entrepreneurial pitches (a brief speech of an entrepreneur to investors) in the TV reality shows Dragons' Den (UK) and Sharks Tank (USA). The article describes pitches studied by modern linguists within the anthropocentric paradigm. The paper considers the concepts 'speech genre', 'communication strategy' through the prism of scientific views of M. M. Bakhtin, O. S. Issers as well as the theory of business discourse in the works by F. Bargiela-Chiappini. The article analyzes the most typical structural, lexical, semantic and stylistic characteristics of the pitch manifested in dynamics. The authors demonstrate that the interaction of business, public and mass media discourses generates a genre that is not reduced to the simple sum of their components. The research shows that taken in the context of mass media communication, pitch as a genre should be considered in all the diversity of this speech situation, allowing us to rethink the genre-forming factors of pitch. The set of specific characteristics that make it special in its capacity of a speech genre includes inequality of the communication role and status, two pools of listeners, preset logical structure of the text, elements of show, turns in the process of speech, number of speakers, and a function of a trigger for further negotiation. A new understanding of the role and meaning of pitch allows us to categorize this genre not as an element of the sales genre but as the first component of the commercial negotiation genre. The results obtained can be applied in the practice of teaching modern English language, in research on communicative linguistics and pragmatics.

Key words: speech genre; business speech; pragmatics; business speech communication; mass media communication; strategy; pitch; communication situation. 
The research examines the speech genre of entrepreneurial pitch delivered in a television reality program format, a 1-3-minute speech deployed by entrepreneurs in front of investors to attract funding. The object under discussion was previously researched and described as entrepreneurial pitch from the position of rhetorical analysis as a discourse model [Guervós 2019], self-marketing speech or 30second rhetoric through the role of narrative and metaphor [Blazkova 2016]. The linguistic phenomenon has been mainly examined as belonging to business discourse addressing its prefabricated structural aspects, overweighting its rhetorical and persuasive effects and incorporated selling techniques. The study is aimed at revealing that role and genre of the entrepreneurial pitch are not limited to sales genre and to its informative function, i.e. transmission of information. Moreover, pitch has less to do with sales than it was previously stated. This new contemporary focus adds to the topicality of the research: the existence of linguistic phenomenon is influenced by multimodal reality which causes its transformations, blending with other genres and discourses and reinventing its main features, role and value. As T. A. Shiryaeva states, "the research of language of business paradigm and the system of interaction of various linguistic levels in the process of professional communication is still in the initial research stage" [Shiryaeva 2018: 82].

The elaborated discourse analysis demonstrated that functions of entrepreneurial pitch are examined as an initial element of business negotiation and networking communication. This factor fulfills the tactics of creating identity and reliable business image, engaging into the further conversation with venture capitalists. The arguments used by the entrepreneurs are perceived by the listeners not as the arguments for making decision to invest or not to invest but for, primarily, creating the image, evaluating the speaker's art and personal talent. From this perspective the pitch is considered to be a starting point for negotiating. The further process of negotiating results in success or failure but not the pitch itself. That is why the research suggests reinventing the value of rhetorical aspects of entrepreneurial pitch understood as "the persuasive communication strategies that demonstrate their effectiveness" [Guervós 2019: 15]. This new understanding of the role and value of entrepreneurial pitch transforms linguistic categorization of a pitch from a sales speech into an initial communication offer to have a conversation.

Historically, entrepreneurial pitch was referred to as a metaphor "elevator pitch". The concept "elevator pitch" emerged from the idea of giving presentation of a business idea in front of the investor(s), normally short of time and presumably caught ready to listen in the elevator, with the goal of persuading to invest in a startup. The notion "elevator speech" dates back to the $\mathrm{XX}^{\text {th }}$ century in the USA where the pillar for elaboration of new schemes of text organization was shaped as regularities in the ways the audience perceives the text and it was further developed as pragmatics of the text. Nowadays, there is a variety of terms: "elevator pitch", "lift pitch" or "elevator speech", all related to the place where the speech is supposed to be pronounced. Normally, in the process of development "elevator pitch" got the definition of a brief, pre-prepared, persuasive speech aimed at sparking investor's interest. Thus, the communicative situation of an elevator pitch denotes situational roles of the participants in the act of communication as an entrepreneur and an investor but not deliberately as a salesman and a customer. Today the development of this specific model of business discourse has been hardly associated with the elevator but with the certain genre of speech limited in time, highly expressive and persuasive with the intention to raise interest or finally to invest [Guervós, 2019]. Pitches have gained popularity and importance and have been practiced in human resources, marketing, self-branding, in startup incubators and in innovative spheres if seeking for financial support. In this article the object of linguistic examination will be fixed as "pitch" limited in its scope to the analysis of the speech for investors as language of business communication researched as a syntactically, semantically and pragmatically organized set of models perceived both from the perspective of a speaker's and a listener's strategy and tactics of communication. In this capacity the described phenomenon reveals as a specific speech genre of business communication.

The purpose and typical strategic models of business communication behaviors of interacting participants imply a set of communication norms. As a source of communication models, business English is examined from the perspective of strategies and principles of speech behaviors in different situations of business communication. In this article business discourse is defined as "a purposeful social activity performed under professional conditions, speech immersed in business context" [Bargiela-Chappini 2007: 3]. Entrepreneurial pitch is one of such situations characterized by standards and norms, speech composition and organization. Speech strategy is characterized by a set of speech actions aimed at communication goal, selection of facts and their outlay in order to influence intellectual, volitional and emotional spheres of the listener. Entrepreneurial pitch, being an element of business discourse, represents strategic process, based on the selection of optimal language resources. In the process of speech interaction, the speaker tends to control the process of communication through directing the listener into 
the desired path, persuading him to a certain decision. The choice of tactics of the pitcher is deliberate and differentiated on the basis of tactic tools on different levels - semantic, pragmatic, stylistic - and rhetorical aspects of speech activity. The intentionality of speech action is an important point. The entrepreneurial pitch is always an intentional planned influence based on persuasion of different nature: rhetoric, logical or argumentative.

Persuasive speech activity is aimed at initiating the interlocutor to behave to the interest of the speaker. Compliance-gaining studies have been the subject of research in American linguistics [O'Keefe 2011]. These studies were centered on the examination of speech strategies of compliance. The speaker tends to witness the planned reaction from the interlocutor. The entrepreneurial pitch is aimed at persuading the investors to invest in the speakers' business. The speech of candidates is well calculated. Rhetorical aspects present intrinsic part of business communication. Speech composition, its structure and pre-prepared outline provide effective and successful outcome, the speaker remains focused and the speech sounds logical and coherent. The plan for effective speech can be detected through the analysis of real-life speeches with reached goals.

\section{Methodology}

One of the prominent works on speech genres was written by M. M. Bahtin [Bahtin 1996]. The scientist states that each speech sphere develops its own repertoire of speech genres, while the language as a whole has a nomenclature of speech genres, the philological description of which is necessary for the study and description of the laws of speech communication [Bahtin 1996: 16]. The importance of his understanding of the term lies in the focus on dynamics in communication. Speech genre is described as a phenomenon in a certain situation of communication, it is necessarily addressed, or, in other words, contains the concept of the addressee and responses. Thus, the speech genre does not exist by itself but only as a part of a whole.

This research is based on the system approach to the levels of structure and function. The current level of development in the field of linguistics demonstrates that the more research instruments are used the more objective results the linguists can derive. The complexity of the linguistic phenomenon under examination prompted the set of general scientific and particular linguistic methods of analysis. The research procedures were realized on the basis of such scientific analytical methods as inductive, comparative, integrated and descriptive methods. The analysis of pitches' texts consisted in examining their syntax, semantics, style and pragmatics. The material was analyzed with the help of the methods of cognitive reconstruction, linguistic interpretation and introspection.

Language activity of a person is essentially interpretative both in understanding linguistic units of any level, speech creativity and in the process of communication. The view of linguistics as a science of interpretation is based on the interpretative understanding of human activity. In this approach interpretation is considered as the process of obtaining an original object, different from it, proposed by the interpreter as an equivalent to the original with a specific background of the situation. In the process of communication understanding is not directly related to the fact that it receives the same or basically the same set of interpretations for the same language expressions. The format of reality show allows to treat the linguistic production as recorded and fixed real-life situations.

Introspection is a component of any communication and one of the basic actively used methods of language research, in particular within the framework of the research tradition based on the ideas of Y. D. Apresyan [Apresyan 1995] and others. Linguists consciously direct their attention to how a particular aspect of the language is perceived in the mind. In fact, in such experiments we are talking about using introspection for the assessment of certain properties of language expressions (specially constructed or found in real speech). The method of introspection is useful as the source of certain reliable facts, which can be based on further reasoning. These facts are considered to be reliable only due to the fact that a person is able to observe them as such in his / her mind. The degree of certainty of such a fact depends on the degree of its availability for introspective observation.

Interpretation and introspection as the methods of linguistic analysis permit to observe, set, assess, analyze and interpret the certain properties of pitches' understanding. Meanings are ascribed to situations of business communication deployed from the initial stage, represented by entrepreneurs' pitching, up to the final investors' decision, to invest or not to invest. In the research, the outcomes of the interpretative process are supported by the procedure of detecting if the interpretation is correct. The procedure consists in finding elements supporting the interpretation in the further Q\&A session, in the deployed polylogue between the main participants of the communication.

The variety of approaches does not cover the systemic theory-driven approach to elevator pitch perceived as a complex, strategically and tactically organized speech genre characterized by specific communicative moves embracing linguistic markers and being an element in a deployable interaction between entrepreneurs and investors. Moreover, the 
previously tapped studies have hardly taken into consideration the speakers' communicative behavior, intentions, presets and goals and also those by their addressees, venture capitalists. The approach emphasizes embedded multilayer of contemporary linguistic analysis embarking from the function of the linguistic phenomenon.

Investigations of language immersed into real-life business and workplace contexts have been growing within considerable discourse analytic and pragmatic studies [Bargiela-Chiappini, 2007; Bargiela-Chiappini, 2009; Planken, 2012]. These fundamental works established research traditions and described emerging trends, providing comprehensive and major developments in the research field of current business discourse.

Speech influence has been profoundly and deliberately researched. Types of discourse differ in the level of intensity of their influence. P. Lakoff singles out "persuasive discourse" [Lakoff 1982: 27]. It is evident that persuasiveness as a function does not mark types of discourse equally, for example "asking the way" as a speech situation functions more informatively than persuasively whereas elevator speech, vice versa, is supposed to persuade. The situation of speech influence presupposes the position of a speaker and an interlocutor. Being an actant in a speech act, the speaker tends to regulate his / her interlocutor intellectually or physically. The speech initiates the partner to start, to finish or to change decision. That is why the actant's position is under analysis of speech influence. R. Lakoff supposes that persuasive discourse happens only under conditions of inequality, when one of participants attempts to influence the interlocutor consciously [Lakoff 1982: 28].

Rituality of speech behavior allows to predict speech actions and to realize strategic approach in standard speech situations [Issers 2017: 18]. In the description of speech, we refer to the toolkit of theory of speech acts, elements of speech genre, theory of semantic fields and discourse analysis. In its capacity as a notion, "strategy" implies two main ideas: that of planning actions related by social confrontation and that of prognosis of the situation (choice of speech strategy and tactic, selection of linguistic means of communication) and the reaction of the interlocutors. Taken as that, strategy is based on the shared grounds between the interlocutors (speaker and addressee), and cognitive social and individual models. It is important to mention that being implemented the strategy cannot guarantee the success. That is why it can be predicted that a certain set of actions will lead to success with a certain percentage of probability to happen. However, the realization of the interaction can fail the prognosis.
The effectiveness of speech strategies is determined by results or consequences of social interaction, regardless of whether the given result is deliberate, consciously planned [Blakar 1987: 92]. $\mathrm{O}$. S. Issers defines a strategy as "a cognitive plan of communication through which a speaker controls the optimal result of his / her communicative tasks under the circumstances of deficiency of information about the further partner's communicative behavior" [Issers 2017: 100]. Though speech strategies have cognitive dimensions, for example, planning and control, the research is built on particularly linguistic and interactional features because they determine the means of reaching the goals.

Pragmatics borrows the term "strategy" from the sphere of military art where the result and effectiveness of actions are calculated in terms of "win" "loss". The competitiveness outweighs cooperation. It explains why the analysis is built on the communicative goals of the speaker and the parameter "cooperation" - "confrontation" forms the basis for two types of speech strategies: cooperative and confrontational [Issers 2017: 70]. It is obvious that pitchers intend to cooperate with the angel investors in future. Perceiving entrepreneurial pitch as a genre, it is important to give genre-forming features. Among the typical genre-forming features, researchers mention the image of the author and the image of the addressee, a factor of future orientation, language tokens, clichés and constructions.

The image of the author and the image of the addressee are the basis of specific speech strategies that accompany communication goals. The notions are borrowed from the theory of speech genres. Strategic aspect of discourse is also bound to predicting possible responses of the interlocutor. Interlocutor's responses to the speech are postulated to be taken into consideration.

Another index of a strategy can be described as a set of linguistic constructions, signals or clichés. Complying with the intention and the situation of communication, the linguistic constructions and signals such as lexical, grammatical will serve as markers of a certain speech act, speech genre and strategy.

The analysis allows to conclude that entrepreneurial pitch as a genre of business discourse is referred to the rhetorical type of strategies. The research stipulates that persuasion serves as a special tactic consisting of many communicative moves.

We refer to communication as to a process in order to find shared grounds between speech influence and speech interactivity. Communication allows observing the effects of mutual influence in the process of constant modification of ideas, settings, values, attitudes, opinions. 
Development of modern mass-media sphere results in emerging of new TV formats which acquire their outlines and functions through hybridization. The diffusion of genres blurs the borders between them.

The source material was taken from TV shows Dragons Den (UK) and Shark Tank (USA), where entrepreneurs prepare elevator speeches to a panel of 5-6 angel investors, called metaphorically dragons, sharks, tigers, who decide whether to invest in their company. The first Rule of the Dragons' Den says to shape the pitch: "Entrepreneurs must start the meeting by stating their name, the name of the business, the amount of money they are pitching for and the percentage of equity they are willing to give away in their company. They must follow this with a pitch of up to three minutes. If it exceeds three minutes, the Dragons can stop entrepreneurs at any point but they cannot interrupt the initial pitch" [Dragon's Den 2019].

\section{Results and Discussion}

The research started from the lexical and syntactic linguistic analysis of entrepreneurial pitch scheme. A typical for an entrepreneurial pitch scheme can look as the following:

"My name is [name] and my business [name of startup project] solves the problem of [nomination of the problem] by providing [advantage]. After carrying out extensive research and by using live testing with a wide range of people who represent our target market, we were able to accomplish [goal].

This unique system which has been developed and patented is the only one of its kind in the world today. With [number] customers already lining up to buy our new system to get [benefit] and with [amount of capital] already banked, we are looking to expand to the next stage.

Our projected sales for the next [number] months is [amount of capital] and we expect to make [amount of capital] profit. Our research has shown that there are [number] potential customers in [name of a country]. World-wide this is estimated at [number]. We are looking for an experienced angel investor who is keen to invest in an exciting one-off opportunity. In return for [amount of capital] investment we are giving away a [percent] stake in our business" [Albertson 2008: 35].

Researched apart from the real situation as a phenomenon in itself and withdrawn from the business communication as a whole negotiating process, the text of entrepreneurial pitch is characterized by the following semantic features:

1. Business-related lexemes: "business", "target market", "customers", "to buy our new system", "banked", "our projected sales", "make [amount of capital] profit", "angel investor", "to invest", "investment", "giving away a [percent] stake".
2. Uniqueness. Displaying "uniqueness" of the business, "USP" (unique selling product) in terms of singling out from the competitors. The lexical range represented, for example, by the adjectives "unique", "exclusive", "exceptional", limiting adverb "only", whole phrase "the only one of its kind in the world today", "one-off opportunity" [Cambridge Dictionary].

3. Problem-solution through the lexemes "solve the problem of", "providing".

4. Numerals in describing financial data.

5. Future-oriented lexemes: "projected sales", "the next [number] months", "expect to make", "potential customers", "expand to the next stage".

Semantic analysis of the text was implemented with the help of the instrument "SEO text analysis online", an online text analysis service. For this research, we referred to such parameter as keyword density and it demonstrated the highest density for the lexemes "business", "already", "customer", "next", "project", "system", "problem" and "research", the density of these lexemes is identical, it equals to $2.9 \%$ in the core and $1.1 \%$ in the text. This instrument allows us to add one more important meaning of "accomplishment" expressed in a lexico-grammatical way through the adverb "already", also lexeme "to accomplish [goal]" and grammatical present perfect tense forms "has been developed and patented", "our research has shown".

Structural formats with their suggested order of elements and focus permit to detect some main strategies with repeating tactics. The following is a standard pitch structural format which is called Strategy "Resisting to competitors" fulfilled by the following tactics:

1. Introducing yourself, position in the company;

2. Product and target audience;

3. Value proposition;

4. Setting out of competition and primary competitive points of difference;

5. Call to action.

Structurally entrepreneurial pitch can also be built on the strategy "Gains" if it includes the following elements of tactics:

1. Introducing yourself;

2. Focus on advantages;

3. Goal of product (service) and its benefits;

4. Your achievements.

The peculiarity of TV shows is a preset scheme or scenario of the show when the perlocutive effect of the speech is pre-calculated. However, the reality TV shows differ because they tend to reflect and imitate the reality as it is, focusing on spontaneity and authenticity of participants' reactions, patterns of behavior and emotions.

The structural scheme of the pitch in the TV reality shows complies with the Strategy "Problem- 
solution" with the following enlisted compulsory tactics:

1. Greeting;

2. Introducing by names;

3. Announcing a sum of funding and suggested stake in the business;

4. Describing the problem;

5. Giving their solution of the problem;

6. Presenting their current achievements and the perspectives;

7. Engaging-contact phase (asking to taste, to touch).

It is worth emphasizing here that the scheme is given to the speakers by the shows' screenwriters. Thus, it can be conceived as working, laconic way and the most effective for the purposes of the TV show. The elements of the pitches' scheme chosen by the shows differ from those found in practice guides and gurus of sales and marketing [Howell 2006; Albertson 2008] by concentration on the strategy "Problem-solution" working better for public TV format. Thus, the strategy "Problem-solution" occurs more interesting and engaging for mass audience of the TV show as well as for the investors and serves the brace and uniting cognitive element for two worlds: business and public mass-media.

Syntactically the first three elements (greeting, introducing by names and announcing a sum of funding and suggested stake in the business) represent the rigid scheme and show minimum of variation, being normally combined in 2 or 3 phrases:

"Hello! Our names are John and John and we are here today to ask you for 75000 pounds in return for $3 \%$ stake in our business craft clubs limited. Our mission is to reinvent the way that drinks lovers discover and enjoy new drinks. The drinks industry is changing. More people are drinking at home and they are choosing quality over quality. They are seeking out new products from craft producers and are left underwhelmed by what's in the supermarket. At the same time the number of craft producers is booming but they have limited marketing budgets and are often left undiscovered. Craft clubs are launching alcohol subscription clubs to connect these craft producers with the home market. Every month we partner with one distillery can, we send their gins to our club members along with our monthly magazine and special treats that go in the box that tell the story of the gin. Sounds fantastic, John, but how does all of that translate into numbers? Our business has been cash flow positive since day one in our first year we acquired 300225 members and turn over 400081 pounds. We are growing quickly. Our current revenue run rate stands at $1.2 \mathrm{mln}$ pounds and will reach $2.7 \mathrm{mln}$ pounds at the end of this year. Our goal is to deliver a 10 times return on your investment. We've got some really delicious crack gin and tonics for you to try and some surprise gin for the month boxes for you to open" [Episode, 2016].

The semantic analysis provided by SEO online resulted in the semantic field distribution between the lexemes "craft" used 5 times, and "drink" and its derivatives -4 times. The field with "drink" is developed with the usage of semantically close words "alcohol", "distillery", "gins" - 4 times. The lexemes create the core of the text ranging from $4.9 \%$ for "craft" and $3.9 \%$ for other 4 lexemes. Other important semantic fields are centered round the lexeme "new" which is embedded explicitly in the combinations "new drinks", "new products" and implicitly in the word "reinvent". The word "reinvent" is defined as "to produce something new that is based on something that already exists" [Cambridge Dictionary]. The idea of "novelty" is rendered with the help of lexemes "reinvent the way", "discover", "new drinks", "changing", "new products", "launching". The linguistic expressions create the emotional effect through the use of positively colored adjectives "fantastic", "booming", "delicious". At the same time the entrepreneurs are presented as active innovators of the industry in the speech. The alcohol industry is conveyed as an object of love ("drinks lovers" and pleasure "enjoy new drinks"). The semantic analysis with the help of SEO online proves that in the utter majority of entrepreneurial pitches pronounced in the reality TV shows the substantives and nominations of the product prevail steadily.

The pitch follows the strategy of "Problem - solution". The problem is described as "More people are drinking at home and they are choosing quality over quality. They are seeking out new products from craft producers and are left underwhelmed by what's in the supermarket. At the same time the number of craft producers is booming but they have limited marketing budgets and are often left undiscovered". It can be interpreted as the growing demand in high quality new alcohol products, customers' dissatisfaction of the products from supermarket and inability of craft producers to reach their clients. The solution provided by the speakers is developing subscription to craft clubs. The business type of information is presented in numerals at the beginning when speaking about the request and the offered stake and at the end where the pitchers mention their achievements and plans.

Stylistically entrepreneurial pitch is featured as neutral business vocabulary, excluding jargon.

In the utter majority of cases the speech is presented by mostly two speakers. Linguistically changing the speaker marks changing the topic of the speech. It functions as fighting with monotony and signposting changing the topic. 
The pitch minimizes personality of entrepreneurs which is limited to their names. This erased personal identity is compensated by the construction of professional identity of the speakers as entrepreneurs, reflected in the correlation between request and offered stake, current achievements and ambitions of announced perspectives. In general, personal aspect of business communication is presented unequally especially in its starting point of interaction which is evidently expressed in the pitches of the TV business reality shows. The language of business is almost devoid of personal characteristics of pitching entrepreneurs. Personality of entrepreneurs is limited to their names whereas the image of the invited eminent investors is well known and open to publicity, the main heroes of the show are aware of it. Identity of investors also equals to experts and close to ideal characteristics of successful highly professional businessmen.

The peculiarity of the TV show resides in show elements in a pitch calculated to produce an effect of positive atmosphere. That is why the speakers tend to induce surprise affecting their emotions and senses through unexpected objects (bringing a dog, food, perfumes in the studio), specially trained actions (hands shaking or dances). It is not possible to underestimate these extra linguistic factors because they do not only accompany the speech but serve their own function within the show.

The elements of show staginess, decorations, clothes, stage set reflect the originality of the participants and influence emotional and affective modalities of investors and audience. TV show format merged with business format deliberately leads to the transformations in the initial part of pitching: the role of businessmen blends with the role of actors, showmen; the pitch incorporates elements of drama, provocation, intrigue, game. Pitching, businessmen act out following the rules of show in order to produce a positive emotional effect, attempting to surprise, and create an atmosphere for a further business conversation which happens in Q\&A session through follow-ups from investors. Thus, entrepreneurs do not start their pitch in an abstract image of businessmen who want to attract funding but in the image created by their first appearance, sometimes in special clothes, with attributes in their hands and stage set around them. At the same time this step of the show, pitching, serves for the investors as the period of creating the initial image of the entrepreneurs expressed in the so-called charisma or aura which is in fact evasive and conceptual as a whole but necessary to create the first sight opinion, judging speakers' personal involvement and level of assuredness and belief. The arguments mentioned above lead to the idea that the pitch provides the prepared image of professional competence of the speakers where they can impress by the current achievements, the tempo of profit growth, and accomplishments. For example:

"... since day one in our first year we acquired 300225 members and turn over 400081 pounds. We are growing quickly. Our current revenue run rate stands at $1.2 \mathrm{mln}$ pounds" [Episode 2016].

However, as the numerous episodes show, this entertaining and emotional part of the show calculated for mass audience does not mainly influence the investors. There is no direct link between the high emotional effect created at the beginning and the final decision. "Dragons" do not calculate their decisions basing on emotions but follow their own interest either to the market sector, e.g. IT project in dating even with poor and emotionless acting of the speaker sounded for them attractive with 5 offers because it was an interesting market sector or their personal interest or existent business in the sphere (e.g. "Gina and Tonic" Episode ended with the deal from the investor-restaurateur or "Calorie Free" Episode was of personal interest to the investor who simply wanted to lose weight) [Episode, 2016; Shark tank, 2019]. It means that due to TV show format pitch fulfills two goals: first to entertain the mass audience and to give preliminary idea of the request for the investors, building preliminary image in terms of current success, ambitions and involvement. The image of the entrepreneurs starts being created before the speech through scene effects, in the process of their speech, reaching its brightest characteristics to the end of the speech and all these characteristics are implicit and indirect, they appear and find evidence in the further conversation.

The pitch serves as a preliminary offer from the entrepreneurs if examined from the point of view of its role and value in the Episode as a whole from the beginning up to the end, where all interactions result in decision. It can be easily seen that pitch as a starting part of the show (maximum 3 minutes) creates the base for further negotiations (in average 1215 minutes).

Regarding pitches as the starting point, investors find the most meaningful parts, these parts are identified in the topics for investors' follow-up questions during Q\&A session. From the point of view of investors, the most meaningful parts of the pitch judging by the follow-up negotiation's focus are as the following:

1. The amount of money asked, the percentage of stake.

2. The properties of the product, details of the product (material, quality, colors, way of manufacturing), location of manufacturing.

3. Information about the company, the location and quantity of the office.

4. Sustainability of the project and its scalability. 
5. The list denotes purely business sphere but not public or mass-media, some bits of information under discussion bear confidential commercial character.

The research stipulates that the persuasion as a tactics in entrepreneurial pitch does not follow the scheme adapted for other types of the genre even in business and other types of discourse. The linguistic means and effect calculated for producing the influence on the emotional level of addressees work out only in the short-term perspective: during and after the entrepreneurial pitch itself and calculated for producing the effect, transfer the initial and brightest idea of the product or service and show for the mass audience. Whereas its effects do not work out in long-term perspective after questions and answers because investors do not regard entrepreneurial pitch itself as a basic factor for making a final decision: to invest or not to invest, they avoid making decisions under emotions due to the domination of rational locus of control in the process of making decisions. At the same time the emotionality and problemsolution character of the speech are performed following all the rules of advertising discourse. The enterprises are aware of the wide audience and the opportunity to impact and attract if not the investors then potential customers.

Being an element of the TV shows, the entrepreneurial pitch can be defined as a type of oral public speech which differs from other types of selling, self-selling formats of entrepreneurial pitches due to the effect of broadcasting. The entrepreneurial pitch presented as an element of the TV shows is characterized by the set of specific characteristics that make it special in its capacity of a speech genre:

1. Number of speakers.

2. Awareness of two pools of listeners: the first pool of investors sitting in front of entrepreneurs and the second pool of a broad audience watching the show.

3. Elements of show: staginess, entertainment, enthrallment, stage set.

4. Turns in the process of speech.

5. Preset logical structure of the text with subtle variations.

6. Inequality of the communication roles: requesting for investment and accepting or refuting the deal.

7. Inequality of status: no name speakers versus popular and successful first pool listeners.

8. Triggering function of the entrepreneurial pitch: serving a starting point in further negotiating process.

The analysis of pitches in TV show format allows to conclude that this linguistic phenomenon represents blending of public, mass-media and business discourses. The most prominent elements of which result in a specific linguistic model based on cognitive, social and communication models.

\section{Conclusion}

The genre is revealed through the complexity of the communicative situation. Taken in the context of mass media communication, pitch as a genre of business professional communication must be considered in all the diversity of this speech situation, allowing us to rethink the functions and role of entrepreneurial speech. The communicative goal of pitch cannot be reduced to rhetoric and persuasive one with the intention to persuade to invest because the pitch is aimed at presenting and informing the listeners, investors, serving the initial stage in the process of business negotiations and professional communication, and at the same time it is oriented to advertising a product or service for the audience in front of TV sets. On the one layer of communication, speakers attempt to create the identity of a reliable, worthy business partners, engaging in a conversation with investors, whereas on the other - entrepreneurs entertain to impact the public. The strategy "Problem-solution" represents a more interesting and engaging format for mass audience of the TV show as well as for the investors and serves the brace and uniting cognitive element for two worlds: business and public mass-media. The existence of linguistic phenomenon is influenced by multimodal reality which causes its transformations, blending with other genres and discourses and reinventing its main features, role and value.

\section{Source material}

Cambridge Dictionary. URL: https://dictionary.cambridge.org/ (accessed 11.05.2020).

Dragons' Den. British Reality show. BBC Two. 2019. 47 Episodes. Available at: https://www.bbc.co. uk/programmes/b006vq92/episodes/guide (accessed 11.05.2020).

Episode. 2016. Gin and Tonic. Dragon's Den. Available at: https://www.youtube.com/watch? $\mathrm{v}=$ EIt U5letwmM (accessed 11.05.2020).

Shark Tank. Reality television series on ABC. 201947 Episodes. Available at: https://abc.com/ shows/shark-tank (accessed 11.05.2020).

\section{References}

Apresyan Yu. D. Izbrannye trudy [Selected works]. Moscow, LRC Publishing House, 1995, vol. 2. Integral'noe opisanie yazyka i sistemnaya leksikografiya [Integral description of the language and system lexicography]. 472 p. (In Russ.)

Bakhtin M. M. Problema rechevykh zhanrov [The issue of speech genres]. Sobr. soch. [Collection of works]. Moscow, Russkie slovari Publ., 1996, 
vol. 5. Raboty 1940-1960 gg. [Works of the1940s1960s], pp. 159-206. (In Russ.)

Blakar R. M. Yazyk i modelirovanie sotsial'nogo vzaimodeystviya [Language as a means of social power]. Moscow, 1987, pp. 88-125. (In Russ.)

Issers O. S. Kommunikativnye strategii $i$ taktiki russkoy rechi [Communication strategies and tactics of Russian speech]. Moscow, URSS Publ., 2017. 308 p. (In Russ.)

Albertson E. How to open doors with a brilliant elevator speech. New Providence, NJ, R. R. Bowker LLC, 2008. 165 p. (In Eng.)

Bargiela-Chiappini F., Nickerson C., Planken B. Business discourse (Research and practice in applied linguistics). New York, Palgrave Macmillan, 2007. 282 p. (In Eng.)

Bargiela-Chiappini F. The Handbook of business discourse. Edinburgh, University Press, 2009. 528 p. (In Eng.)

Blazkova H. Generating word-of-mouth via organized business networks: the role of narrative and metaphor in 60-second self-marketing speeches. A thesis submitted to the University of Birmingham for the degree of Doctor of Philosophy, The University of Birmingham, 2016. 462 p. (In Eng.)

Guervós S. J. Rhetorical analysis of a discourse model in the business world: 'Elevator Pitch'. Círculo de lingüistica aplicada a la comunicación (Retórica, discurso, persuasión), 2019, pp. 7-16. Available at: https://dx.doi.org/10.5209/clac.66597 (accessed 11.05.2020). (In Eng.)

Howell L. Give your entrepreneurial pitch a lift. Bothell, WA, Publishers Network, 2006. 332 p. (In Eng.)

O'Keefe D. J. Generalizing about the persuasive effects of message variations: The case of gainframed and loss-framed appeals. Bending opinion: Essays on persuasion in the public domain. Ed. by T. V. Haaften, H. Jansen, J. D. Jong, \& W. Koetsenruijter. Netherlands, Leiden University Press, 2011, pp. 117-131. (In Eng.)

Lakoff R.T. Persuasive discourse and ordinary conversation, with examples of advertising. Analyzing discourse: text and talk. Ed. by D. Tannen. Georgetown University Press, 1982, pp. 25-42. (In Eng.)

Planken B. The changing landscape of business communication: developments and directions in research. In The language factor in international business: new perspectives on research, teaching and practice. Ed. by Priscilla Heynderickx [et al.]. Bern, Peter Lang AG, International Academic Publishers, 2012, pp. 17-41. (In Eng.)

Shiryaeva T. A., Gelyaeva A. I., Alikaev R. S., Huchinaeva D. D., Toguzaeva M. R. A theorydriven framework for the study of language in business. XLinguae, pp. 82-90. Available at:
http://www.xlinguae.eu/files/XLinguae1 2018 8.pdf (accessed 11.05.2020). (In Eng.)

\section{Список литературы}

Апресян Ю. Д. Избранные труды. Т. 2. Интегральное описание языка и системная лексикография. М.: Языки рус. культуры, 1995. 767 с.

Бахтин М. М. Проблема речевых жанров // Бахтин М. М. Собр. соч. М.: Русские словари, 1996. Т. 5: Работы 1940-1960 гг. С. 159-206.

Блакар Р. М. Язык как инструмент социальной власти // Язык и моделирование социального взаимодействия. М., 1987. С. 88-125.

Иссерс О.С. Коммуникативные стратегии и тактики русской речи. M.: URRS, 2017. 308 c.

Albertson E. How to open doors with a brilliant elevator speech. New Providence, NJ: R. R. Bowker LLC, 2008. 165 p.

Bargiela-Chiappini F. Nickerson C., Planken B., Business Discourse (Research and Practice in Applied Linguistics). N. Y.: Palgrave Macmillan, 2007. $282 \mathrm{p}$.

Bargiela-Chiappini F. The Handbook of Business Discourse. Edinburgh: University Press, 2009. $528 \mathrm{p}$.

Blazkova $H$. Generating word-of-mouth via organized business networks: the role of narrative and metaphor in 60-second self-marketing speeches // A thesis submitted to the University of Birmingham for the degree of Doctor of Philosophy, The University of Birmingham, 2016. 462 p.

Guervós S. J. Rhetorical Analysis of a Discourse Model in the Business World. Elevator Pitch in Círculo de lingüística aplicada a la comunicación (Retórica, discurso, persuasión), 2019. P. 7-16. URL: https://dx.doi.org/10.5209/clac.66597 (дата обращения: 11.05.2020).

Howell L. Give your entrepreneurial pitch a lift. Bothell, WA: Publishers Network, 2006. 332 p.

$O$ 'Keefe D. J. Generalizing about the persuasive effects of message variations: The case of gainframed and loss-framed appeals // Haaften T. V., Jansen H., Jong J. D., Koetsenruijter W. (Eds.), Bending opinion: Essays on persuasion in the public domain. The Netherlands: Leiden University Press, 2011. P. 117-131.

Lakoff R.T. Persuasive discourse and ordinary conversation, with examples of advertising // Tannen D. (Ed.) Analizing discourse: text and talk. Georgetown University Press, 1982. P. 25-42.

Planken $B$. The changing landscape of business communication: developments and directions in research. In The language factor in international business: new perspectives on research, teaching and practice / Priscilla Heynderickx ... [et al.]. Bern: Peter Lang AG, International Academic Publishers. 2012. P. 17-41. 
Shiryaeva T.A. A theory-driven framework for the study of language in business / Shiryaeva T. A., Gelyaeva A. I., Alikaev R. S., Huchinaeva D. D.,
Toguzaeva M. R. // XLinguae, 2018. P. 82-90. URL: http://www.xlinguae.eu/files/ XLinguae1_2018_8.pdf (дата обращения: 11.05.2020).

\section{ПЕРЕОСМЫСЛЕНИЕ ПИТЧА КАК РЕЧЕВОГО ЖАНРА В ДЕЛОВОМ ОБЩЕНИИ}

\section{Татьяна Леонидовна Копусь}

к. филол. н., доцент Департамента языковой подготовки

Финансовый университет при Правительстве Российской Федерации

125993, Россия, г. Москва, Ленинградский просп., 49. tlkopus@fa.ru

SPIN-код: 7478-2763

ORCID: http://orcid.org/0000-0002-7762-0043

ResearcherID: J-4704-2015

\section{Ирина Иосифовна Климова}

к. филол. н., профессор Департамента языковой подготовки

Финансовый университет при Правительстве Российской Федерации

125993, Россия, г. Москва, Ленинградский просп., 49. iiklimova@fa.ru

SPIN-код: 9951-3145

ORCID: http://orcid.org/0000-0001-5142-1890

Статья поступила в редакциию 12.05.2020

Проведено исследование системообразующих характеристик питча как жанра деловой речи в деловой речевой коммуникации. Материал исследования представлен выборкой из 54 предпринимательских питчей (краткой речи предпринимателя перед инвесторами) в телевизионных реалити-шоу Dragons' Den (Великобритания) и Sharks Tank (США). Статья посвящена описанию питчей, изучаемых современными лингвистами в рамках антропоцентрической парадигмы. Рассматриваются понятия «речевой жанр», «коммуникативная стратегия» с точки зрения научных взглядов М. М. Бахтина, O. C. Иссерс, а также теории делового дискурса в работах Ф. Барджела-Кьяппини (F. BargielaChiappini). Анализируются наиболее типичные структурные, лексико-семантические и стилистические характеристики питча, проявляющиеся в процессе речевой деятельности, в динамике. Методика исследования состоит в изучении синтаксиса, семантики, стиля и прагматики питчей, а также элементов когнитивного анализа для реконструкции элементов образа говорящего и слушающего, метода лингвистической интерпретации и метода интроспекции. Авторы полагают, что при взаимодействии факторов деловой, публичной и массмедийной коммуникации порождается жанр, не сводимый к механической сумме их составляющих. Исследование показывает, что взятый в контексте массмедийной коммуникации питч как жанр следует рассматривать во всем многообразии данной речевой ситуации, что ведет к переосмыслению жанрообразующих факторов питча. Новое понимание роли и значения питча позволяет категоризовать его не в рамках одного из элементов, составляющих жанр продаж, а как наиболее значимый элемент жанра коммерческих переговоров. Полученные результаты могут найти применение в практике преподавания современного английского языка, в исследованиях по коммуникативной и прагматической лингвистике.

Ключевые слова: речевой жанр; деловая речь; прагматика; деловая речевая коммуникация; массмедийная коммуникация; стратегия; питч; коммуникативная ситуация. 